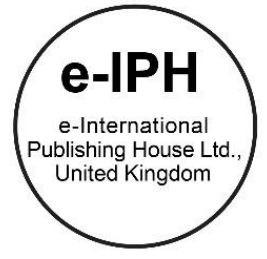

\title{
Investigating User Perception of High-Performance Schools about Factors Associated with Building Energy Efficiency
}

\author{
Mohd Najib Mohd Salleh 1*, Mohd Zin Kandar ${ }^{2}$, Siti Rasidah Md Sakip ${ }^{3}$ \\ ${ }^{1}$ School of Housing, Building \& Planning, Universiti Sains Malaysia, 11800 USM, Penang, Malaysia \\ ${ }^{2}$ Faculty of Build Environment, Universiti Teknologi Malaysia, 81310 UTM, Johor, Malaysia \\ ${ }^{3}$ Faculty of Architecture, Planning \& Surveying, Universiti Teknologi MARA Perak, 32610 Seri Iskandar, Perak, Malaysia
}

\begin{abstract}
Energy demand in buildings can be reduced by improving energy efficiency. MS1525 has recommended that energy efficiency for NonResidential Buildings in Malaysia to be not more than $135 \mathrm{kWh} / \mathrm{m}^{2} /$ year. A school building is a non-residential building and has major social responsibilities. Based on the theory of building energy-efficiency, energy efficiency can be achieved through three main factors: a) design of buildings; b) design of services; and c) user behavior. This study aims to investigate the user perceptions in High-Performance Schools. The questionnaire viewed three main perceptions of users: perception of user behavior, the perception of building design and perception of services design.

(C) 2016. The Authors. Published for AMER ABRA by e-International Publishing House, Ltd., UK. Peer-review under responsibility of AMER (Association of Malaysian Environment-Behaviour Researchers), ABRA (Association of Behavioural Researchers on Asians) and cE-Bs (Centre for Environment-Behaviour Studies, Faculty of Architecture, Planning \& Surveying, Universiti Teknologi MARA, Malaysia.
\end{abstract}

Keywords: User perception; building energy index; building energy efficiency; school building

\section{Introduction}

Level rise of sea level due to global warming, climate change and impact of greenhouse-gas emissions has resulted in the depletion of the ozone layer and thus the destruction and loss of bio diversity natural habitat (Filippín, 2000). Increased energy consumption is a major factor affecting global warming. Energy use in buildings has been identified to account for $40 \%$ of the world's energy consumption, $25 \%$ of water consumption and $40 \%$ of the world's resources (United Nations Environment Program, 2015). Building use also rank third in world greenhouse gas emissions resulting from its use. However, buildings also potentially reduce energy consumption between $30 \%$ and $80 \%$ (Salleh, Kandar, \& Md Sakip, 2015). Today the usage always increased in line with development and modernization, especially in developing countries like Malaysia. By 2020, energy demand in Malaysia is expected to continue to rise with the construction sector being identified as a major consumer of electricity at a rate of $48 \%$ (Hassan, Zin, Majid, Balubaid, \& Hainin, 2014). Energy consumption in Malaysia is lagging behind this increase, reaching a 3-fold increase in 49 years from 1965 to 2014 (Figure 1). It is considered a normal situation experienced by developing

\footnotetext{
* Corresponding author. Tel.: +0-000-000-0000

E-mail address: najib@usm.my
}

(C) 2016. The Authors. Published for AMER ABRA by e-International Publishing House, Ltd., UK. Peer-review under responsibility of AMER (Association of Malaysian Environment-Behaviour Researchers), ABRA (Association of Behavioural Researchers on Asians) and cE-Bs (Centre for EnvironmentBehaviour Studies, Faculty of Architecture, Planning \& Surveying, Universiti Teknologi MARA, Malaysia. 
countries in meeting the needs throughout the country due to improving living standards. Economic relations and energy consumption are directly proportional to each other in many developing countries, including Malaysia. Earth Trends projected that the Malaysian Gross Domestic Product (GDP) is due to increase from 1975 to 2000 in tandem with an increase in energy consumption (H. Byrd, 2008).

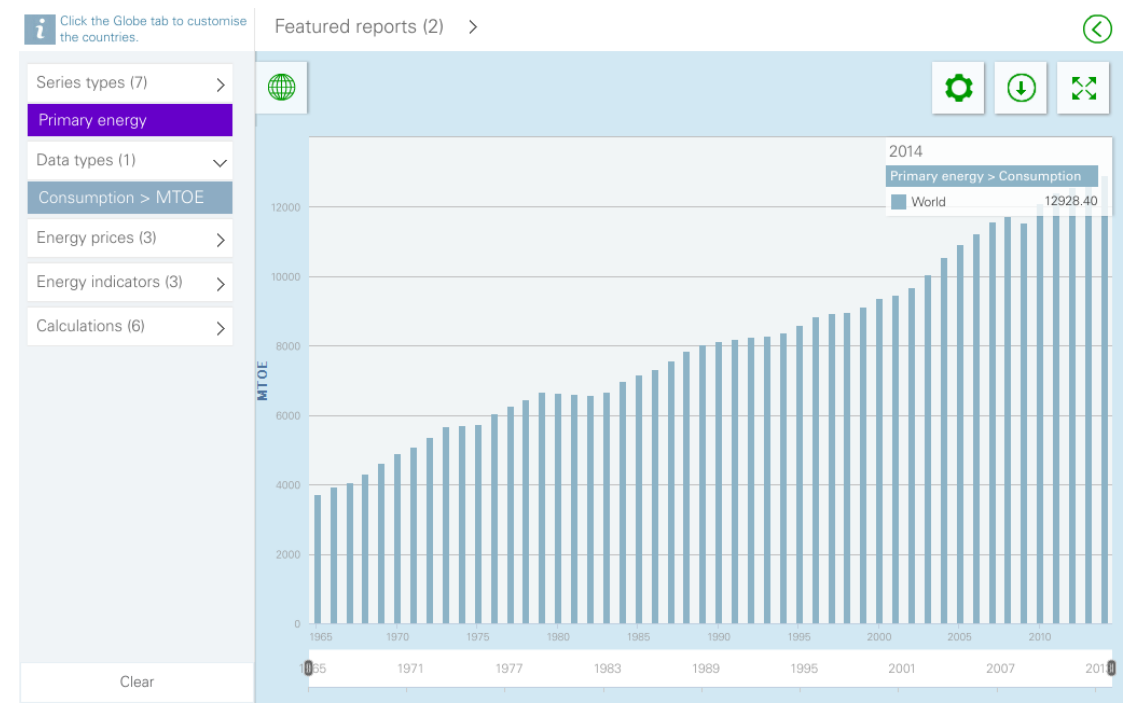

Fig. 1. Primary Energy Consumption 1965 - 2014 (Malaysia). Source: (BP, 2015)

Concurrently, increased energy also improves the amount of greenhouse-gas emissions (greenhouse gas or GHG) (Schipper \& Saidur, 2009). Malaysia recorded a 31.2\% increase in electricity consumption from 2000 to 2010 and thus needs to intensify energy-efficiency initiatives. It is a string of final energy demand of a projected increase of nearly $80 \%$ in 2030 (Government of Malaysia, 2010). The effect of this increase that is a major contributor to climate change should be addressed which requires identifying and understanding the factors contributing to building energy consumption.

\subsection{Energy efficiency}

Energy efficiency in buildings is influenced by three (3) factors namely: a) design of the buildings; b) operation and maintenance; and c) user behavior (Al-Mofleh, Taib, Mujeebu, \& Salah, 2009). Behavioral factors strongly influence the energy efficiency of buildings. It is caused by users who have direct relationships to the treatment in an area and carrying out their activities (Hoes, Hensen, Loomans, De Vries, \& Bourgeois, 2009). It shows the user's behavioral patterns substantially affect the energy consumption in buildings. Normally, the user behavioral studies diagram is based upon the assumption of no implementation of measurement or observation prediction model. These assumptions lead to limitations on the simulation results and produce poor results. Hence, differences in results for energy efficiency based on expected, rather than real performance will happen.

This was evident when the study produced results without taking into consideration the users in the simulation analysis in the case of energy wastage in buildings when they are not occupied (Masoso \& Grobler, 2010). Building energy consumption behavior was starting to get the attention of researchers as early as the 1970s, after the energy crisis (Bin, 2012). Most research involving user behavior is focused upon the behavior of energy consumption in residential buildings although this concentration has since shifted to commercial buildings. The study on user behavior and energy consumption in institutional buildings are rare such as that produced by Ron Widman (Widman, Kaplan, \& Young, 1984).

The importance of the study on energy consumption behavior in buildings has been stated by the PowerSave School Program in which a reduction of $5 \%$ to $15 \%$ is based upon changes in consumer behavior in schools (The Alliance to Save Energy, 2012). This proves that consumer behavior towards energy efficiency is the real issue greatly affecting the issue of 
energy consumption in buildings. This argument can be seen through Lee Shipper's insinuation: "... those of us, who call ourselves energy analysts have made a mistake. We have analyzed energy. We should have analyzed human behavior" (Lutzenhiser, 1993).

There are various methods used to assess the energy performance of buildings. Among the methods is assessment after the occupation "Post Occupancy Evaluation" (POE) as a guide to check the physical design of the building in addition to involving the users to get the real perception through the use of energy efficiency, apart from exploring the knowledge at the level of greenhouse-gas emissions (Wheeler, Boughlagem, \& Malekzadeh, 2011).

Therefore, this study aims to investigate the attitudes and behaviors of the users in High-Performance Schools (HPS). The study involved 140 respondents in two schools from the Northern Zone HPS. The questionnaire investigates three main perception of users: Perception of User Behavior (PUB), Perception of Building Design (PBD) and Perception of Services Design (PSD).

The research questions formed are: Have the school achieved the index proposed standards? If it has, what is the perception of consumers towards energy efficiency in the school building? This study aims to investigate and identify the BEl in the schools. The limitation of the study is taking all buildings within a school border as a School. The researchers have collected monthly energy consumption data for the years 2012, 2013 and 2014. Taking into account the gross floor area of buildings, the BEI calculation using Excel and trend analysis of energy has been used to build the index.

The results obtained fulfilled the Malaysian Standard MS 1525 study of user perceptions and their relationships to the energy efficiency of buildings and the benchmark performance. This paper aims to discuss appropriate methods to benchmark energy efficiency in school buildings using building energy-efficiency theory. The discussions will determine appropriate methods to support the decisions in energy efficiency benchmarking in school buildings.

\subsection{School building}

Malaysia has also established a code of practice for guidance on the effective use of energy, which includes the application of renewable energy in new and existing non-residential buildings. Based on MS1525, the recommended Building Energy Index (BEI) for Non-Residential Buildings in Malaysia is not more than $135 \mathrm{kWh} / \mathrm{m}^{2} / \mathrm{year}$ (SIRIM Berhad, 2007).

A school building is a non-residential building and has major social responsibilities; hence building energy performance in schools is crucial. BEl for school buildings is not relevant to the proposed index levels recommended for non-residential buildings. The BEI of all school buildings is below the proposed index.

Unfortunately, the significance and control of energy consumption in schools are not monitored by specific energy efficiency programs. Results from the All Malaysia Secondary School Energy and Renewable Energy (KT \& DT) Efficiency Project Contest in 2003 recorded findings of school building energy Indices (BEI) averaging $19 \mathrm{kWh} / \mathrm{m}^{2} /$ year to $10 \mathrm{kWh} / \mathrm{m}^{2} /$ year (Salleh, 2008).

In the construction of new school buildings, energy saving through the cover and initial designs can be dealt with during the pre-design phase of the building. An optimal design of the building envelope can be considered during the preparation process and the reduction of provisions that are more useful. In Malaysia, the hot and humid climate may adversely affect the comfort levels of building occupants.

According to ASHRAE Standard 55-1996, thermal environmental conditions in classrooms indicate the needs for human occupancy comfort in terms of temperatures between $24-28{ }^{\circ} \mathrm{C}$, relative humidity of $20-70 \%$ and average air movement of at least $0.8 \mathrm{~m} / \mathrm{s}$ (ASHRAE, 1996). Referring to Bayer et al. (2000), schools in the United States suffer from serious problems of microbial and inferior Indoor Air Quality when the relative humidity is high at an average of $70 \%$. Students at the schools reported experiencing discomfort and inability to pay full attention to their studies. Meanwhile in Saudi Arabia, high temperatures during the day and low temperatures at night may adversely affect the comfort of building occupants. Although residents and officials can customize their clothing and activities significantly in response to any heat stresses in their environment, the freedom of residents to do the same thing in schools is, to a certain extent, limited (Al-Rubaih, 2008). Thus, thermal comfort in classrooms should be considered carefully, especially because of the effects a high density of occupants in the classroom, as well as the negative impact of unfavorable thermal environment, can have on learning and achievement.

Researchers have studied temperature ranges associated with better learning for decades. The temperature range appropriate to the learning of mathematics is $68-74 \circ \mathrm{F}$, and the ability to study this subject is affected by temperatures above $74 \circ \mathrm{F}$. When temperatures and humidity levels rise, respondents reported more discomfort, their achievement will decline, and 
their level of concentration decreases (King J \& RW, 1979). Lackney (1999) showed that teachers believe thermal comfort affects both the quality of teaching and the student's achievement.

\section{Building Energy Index}

Building Energy Index (BEI) is defined as the total energy consumption namely total electrical energy (or electricity equivalent) consumed by the building in kWh per annum. This includes all energy consumed by the Gross Floor Area (occupied and unoccupied) in buildings including energy for ICT but excluding energy produced by Renewable Energy (Building Consumption Input \& System, 2013).

$$
\begin{aligned}
& \text { Building Energy Index (BEI) }\left[\mathrm{kWh} / \mathrm{m}^{2} / \text { year }\right] \\
& =\frac{\text { Total Energy Consumption a year }[\mathrm{kWh} / \text { year }]}{\text { Total Occupied or Net Floor Area }\left[\mathrm{m}^{2}\right]}
\end{aligned}
$$

Energy consumption for 2012, 2013 and 2014 for the two schools in the study was obtained from the school database. This study aims to get the total average annual energy consumption. Direct data has helped to identify trends in the use of energy for school buildings based on their total area.

Table 1 shows the electricity consumption per unit area of $3.47 \mathrm{kWh} / \mathrm{m}^{2} / \mathrm{year}$ for SM Sains Raja Tun Azlan Shah (SERATAS) (top) while the SBP Integrasi Gopeng (below) was at $3.26 \mathrm{kWh} / \mathrm{m}^{2} / \mathrm{year}$. The BEI difference was calculated to be 0.21 $\mathrm{kWh} / \mathrm{m}^{2} /$ year.

Table 1. BEI Table for SERATAS and SBP Integrasi Gopeng in 2012, 2013 and 2014

\begin{tabular}{lllll}
\hline Name & $\begin{array}{l}\text { Electricity consumption } \\
(\mathrm{kWh})\end{array}$ & $\begin{array}{l}\text { Electricity expenses } \\
(\mathrm{RM})\end{array}$ & Building Area $\left(\mathrm{m}^{2}\right)$ & $\begin{array}{l}\text { Building Energy Index (BEI) } \\
\left(\mathrm{kWh} / \mathrm{m}^{2} / \mathrm{year}\right)\end{array}$ \\
\hline $\begin{array}{l}\text { SM Sains Raja Tun Azlan } \\
\text { Shah }\end{array}$ & $30,715.11$ & $14,018.99$ & 8847.79 & 3.47 \\
SBP Integrasi Gopeng & $34,767.42$ & $16,113.28$ & 10660.4 & 3.26 \\
\hline
\end{tabular}

\section{Methodology}

This study involved two High Performance Schools (HPS) in the Northern Zone of Malaysia in the Science Secondary School Boarding School category namely SM Sains Raja Tun Azlan Shah (SERATAS) and SBP Integrasi Gopeng (SBPI). 140 respondents participated in this study: 70 respondents in SERATAS and 70 respondents in SBPI. The respondents involved in this study were teachers, staff and Form Five students who form the highest level in secondary schools. The selection of students is important because it is based on the age factor of students where a 17-year-old is considered matured enough to have a good understanding of his/her needs and responsibility towards the school.

The questions on the questionnaire are intended to measure the attitude as well as the sense of responsibility of respondents towards the school, especially in terms of electricity used and comfort level about space. An in-person interview approach was used for the purpose of this study to ensure that the respondents fully understand the questions that were forwarded to them. To avoid any confusion or misunderstanding, the researchers introduced themselves as well as explained the purpose the study was undertaken.

\section{Findings}

The questionnaire contains four parts: Part A - demographic background, Part B - perception of user behavior (PUB), Part C - perception of building design (PBD) and Part $D$ - perception of services design (PSD). All variables were measured using a 5- 
point Likert Scale of 1 - strongly disagree, 2 - disagree, 3 - agree, 4 - highly agree and 5 - strongly agree. This questionnaire has undergone a pilot survey to identify any circumstances reflecting unreliable questions. Based on the output from the pilot survey, the questions (Salleh et al., 2015) were restructured for this study. The validation and confirmation of all constructs were done using Exploratory Factor Analysis (EFA). EFA is used to gather information about the interrelationship between a set of variables (Pallant, 2005). The result in reliability level was found by calculating the Cronbach's Alpha. The result indicated that the PUB variable has a good reliability value as the Cronbach's Alpha values were (a) PUB; $a=0.74$, PBD; $a=0.81$ and PSD; $a$ $=0.83$. However, two items in PBD were eliminated because the corrected item-total correlation value is below 0.3. All variables have a Cronbach's Alpha value exceeding 0.60 (Nunnally, J.C. \& Bernstein, 1994) as shown in Table 1.

Table 2. Cronbach's Alpha value for all variables

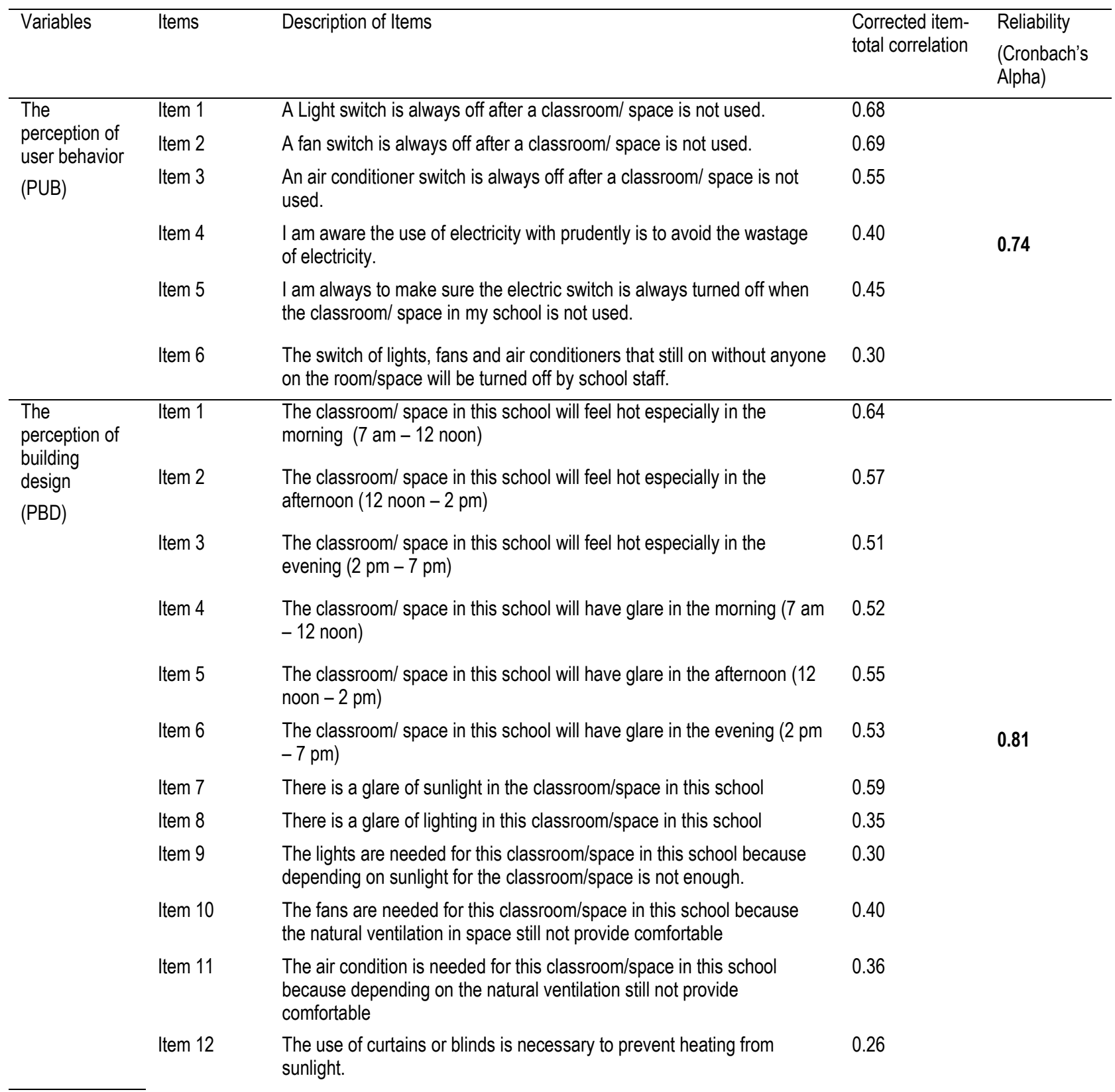




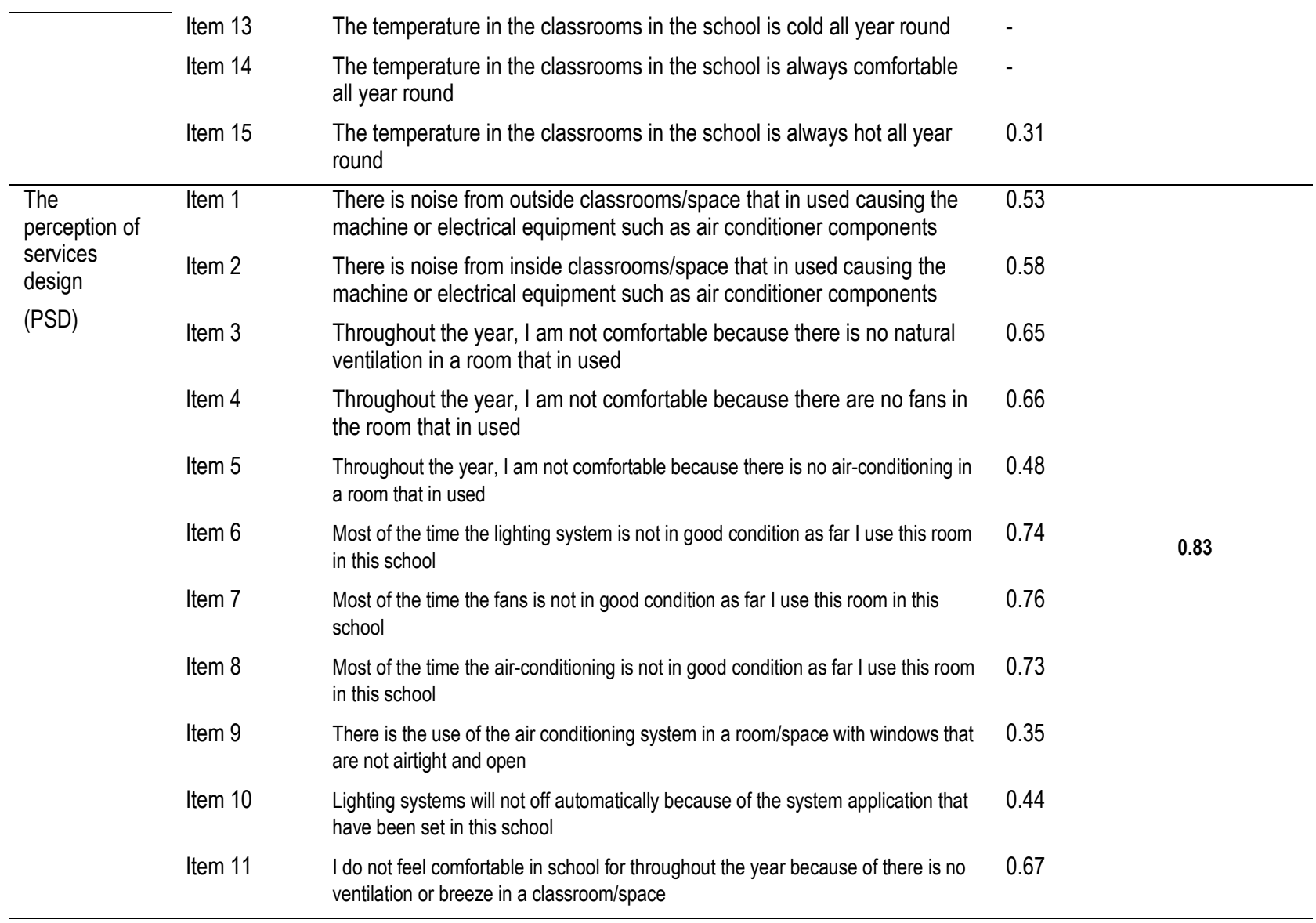

Note: $($ - ) = Items eliminated because the corrected item-total correlation were below 0.3

The respondents involved in this study are $39.1 \%$ male and $60.9 \%$ female $(n=140)$. This includes $85.4 \%$ students; $11.7 \%$ teachers; and $2.9 \%$ staff. The age ranges were between 16 to 20 years old $(85.4 \%)$; with $2.9 \%$ between 26 to 30 years old; $5.1 \%$ between 31 to 35 years old; $0.7 \%$ between 36 to 40 years old; $1.5 \%$ between 41 to 45 years old and between 46 to 50 years old; and $2.9 \%$ between 51 to 55 years old. A total of $89.8 \%$ respondents have served and studied in the school for 1 to 5 years; $2.2 \%$ have served and studied for 5 to 10 years; and only $8 \%$ served in the school for more than 11 years.

After conducting a t-test analysis on types of school with perception of user behavior (PUB), perception of building design (PBD) and perception of services design (PSD) in two different schools, the result found that types of school have significant differences in scores for SERATAS $(M=39.77, S D=7.59)$ and SBPI $[(M=42.75, S D=6.96) ; t(131)=--2.35, p=0.02]$ with PBD. There are also significant differences between types of school with PSD for SERATAS $(M=23.19, S D=5.85)$ and $S B P I[(M=29.01$, $S D=7.15) ;$ ); $t(130)=--5.11, p=0.00]$.

One of the objectives of this paper is to examine differences in PUB, PBD and PSD for SERATAS and SBPI. The result from t-test analysis on respondent status in PUB, PBD and PSD for SERATAS shows significant differences between respondent status and PUB [Teacher $(M=22.81, S D=2.69)$, student $(M=20.70, S D=2.90) ; t(68)=2.27, p=0.02$ ], but no significant differences with PBD and PSD. The result was also similar at SBPI for respondent status with PUB [Teacher $(M=22.81, S D=2.69)$, student $(M=20.70, S D=2.90) ; t(68)=2.27, p=0.02$ ], but not significant with PBD and PSD. T-test analysis between gender and PUB, PBD and PSD found no significant differences between SERATAS and SBPI.

One-way between groups' analyzes of variance (ANOVA) was conducted to explore the impact of age and years of service \& study on PUB, PBD, and PSD. Age groups were divided into four: (Group 1: 16 to 25 years old; Group 2: 26 to 35 years old; Group 3: 36 to 45 years old; and Group 4: 46 to 55 years old). There was a statistically significant difference at the $p<0.05$ level in PUB (SERATAS: $F(3,66)=3.7, p=0.01$; $\operatorname{SBPI} F(3,66)=3.7, p=0.01$ ). However, there were no statistically significant differences for PBD and PSD in both schools. The effect, calculated using eta squared was 0.01 and considered as a small 
effect. For the number of years of service and study at the school, they were divided into three groups: (Group 1: 1 to 5 years; Group 2: 6 to 10 years; and Group 3: 11 years and above).The results from ANOVA analysis for both schools in terms of PUB, PBD and PSD found that there was a statistically significant difference between the number of years service and study at the school group in terms of PUB (SERATAS: $F(2,67)=6.08, p=0.00$; SBPI : $F(2,67)=6.08, p=0.00$ ). However, there was no statistically significant difference in terms of PBD and PSD in both schools. The effect, calculated using eta squared at 0.15 is considered as a large effect (Cohen, 1988). The correlations between perception of user behavior (as measured by the PUB) with the perception of design building (as measured by the PBD) and the perception of services design (as measured by the PSD) were investigated using Pearson product-moment correlation coefficient. The results are as shown in Table 2. The output shows that there was a medium, positive correlation between the two variables $[r=0.387, n=125, p=0.00$ ), with the perception of building design and the perception of services design. However, there are no significant correlations between the other variables.

Table 3. Pearson product-moment correlation between the perception of user behavior with the perception of building design and the perception of services design

\begin{tabular}{|c|c|c|c|c|}
\hline & & $\begin{array}{l}\text { The perception of } \\
\text { user behavior (PUB) }\end{array}$ & $\begin{array}{l}\text { The perception of } \\
\text { building design (PBD) }\end{array}$ & $\begin{array}{l}\text { The perception of } \\
\text { services design (PSD) }\end{array}$ \\
\hline \multirow{3}{*}{$\begin{array}{l}\text { The perception of } \\
\text { user behavior (PUB) }\end{array}$} & Pearson Correlation & 1 & & \\
\hline & Sig. (2-Tailed) & & & \\
\hline & N & 138 & & \\
\hline \multirow{4}{*}{$\begin{array}{l}\text { The perception of } \\
\text { building design (PBD) }\end{array}$} & Pearson Correlation & .127 & 1 & \\
\hline & Sig. (2-Tailed) & .148 & & \\
\hline & $\mathrm{N}$ & 131 & 133 & \\
\hline & Pearson Correlation & -.138 & $.387^{* *}$ & 1 \\
\hline \multirow{2}{*}{$\begin{array}{l}\text { The perception of services design } \\
\text { (PSD) }\end{array}$} & Sig. (2-Tailed) & .118 & .000 & \\
\hline & $\mathrm{N}$ & 130 & 125 & 132 \\
\hline
\end{tabular}

**. Correlation Is Significant At The 0.01 Level (2-Tailed)

\section{Conclusion}

The main objective of this paper is to investigate user perceptions in high-performance schools in reference to factors associated with energy efficiency in buildings through perception of user behavior (PUB), perception of building design (PBD) and perception of services design (PSD). This study found that items adopted to measure both constructs achieved good reliability values as the Cronbach's Alpha ( $\alpha$ ) of PUB; $a=0.74$, PBD; $a=0.81$ and PSD; $a=0.83$. The study also found that there were significant and positive relationships between the two variables of perception of building design (PBD) and perception of services design (PSD) $[r=0.387, n=125, p=0.00)$. The cost for electricity expenses was RM 1.54 per meter ${ }^{2}$ per annum. The BEI for both schools was calculated at $3.365 \mathrm{kWh} / \mathrm{m}^{2} /$ year. This study may aid during the design and management stages as guidelines in energy efficiency school design requirements.

\section{Acknowledgements}

The researchers would like to thank the Ministry of Education Malaysia (KPM), the Perak State Education Department, Sekolah Menengah Sains Raja Tun Azlan Shah (SERATAS), Sekolah Berasrama Penuh Integrasi Gopeng (SBPI) and Universiti Sains Malaysia for their full cooperation and support towards the successful implementation of this study. Special thanks are also accorded to all the respective teachers, students and staff as users within the study areas for their invaluable cooperation.

\section{References}

Al-Mofleh, A., Taib, S., Mujeebu, M. A., \& Salah, W. (2009). Analysis of sectoral energy conservation in Malaysia. Energy, 34(6), 733-739. 
Al-Rubaih, M. S. (2008). Energy-Efficient Envelope Design For Schools in Saudi Arabia. King Fahd University of Petroleum \& Minerals.

Bin, S. (2012). Greening Work Styles: Analysis of Energy Behavior Programs in the Workplace. Techniques (Vol. 20045).

BP. (2015). Energy charting tool. Retrieved from http://www.bp.com/en/global/corporate/about-bp/energy-economics/energy-charting-tool.html

Building Consumption Input, \& System. (2013). Method to Identify Building Energy Index (BEI), NET BEI, GFA, NFA, ACA. Malaysia.

Cohen, J. (1988). Statistical power analysis for the behavioral sciences. Hillsdale: NJ: Erlbaum.

Filippín, C. (2000). Benchmarking the energy efficiency and greenhouse gasses emissions of school buildings in central Argentina. Building and Environment, 35, 407-414.

Government of Malaysia. (2010). Tenth Malaysia Plan. Percetakan Nasional Malaysia Berhad, Headquarters, Kuala Lumpur., 253-327.

Hassan, J. S., Zin, R. M., Majid, M. Z. A., Balubaid, S., \& Hainin, M. R. (2014). Building Energy Consumption in Malaysia: An Overview, 7, $33-38$.

Hoes, P., Hensen, J. L. M., Loomans, M. G. L. C., De Vries, B., \& Bourgeois, D. (2009). User behavior in whole building simulation. Energy and Buildings, 41, 295-302.

King J, \& RW, M. (1979). The physical environment and the learning process: A survey of recent research. Architectural Research Laboratory.

Lackney, J. A. (1999). Assessing School Facilities for Learning/Assessing the Impact of the Physical Environment on the Educational Process: Integrating Theoretical Issues with Practical Concerns, 36.

Lutzenhiser, L. (1993). Social and Behavioral Aspects Of Energy Use. Annu. Rev. Energy Environ., 18(2), 47-89.

Masoso, O. T., \& Grobler, L. J. (2010). The dark side of occupants' behavior on building energy use. Energy and Buildings, 42, $173-177$.

Nunnally, J.C. \& Bernstein, I. . (1994). Psychometric Theory. New York: McGraw-Hill.

Pallant, J. (2005). SPSS Survival Manual; A Step by Step Guide to Data Analysis Using SPSS for Windows. Sydney, Australia: Allen \& Unwin.

Salleh, M. N. M. (2008). Reka Bentuk Sekolah Kebangsaan Daripada Aspek Kecekapan Tenaga: Kajian Kes Di Daerah Perak Tengah [LB3221. N162 2008 f rb]. Universiti Sains Malaysia. Retrieved from http://eprints.usm.my/9095/

Salleh, M. N. M., Kandar, M. Z., \& Md Sakip, S. R. (2015). Users 'Perception of Energy Efficiency in School Design. Procedia - Social and Behavioral Sciences, 170, 155-164.

Schipper, L., \& Saidur, R. (2009). Energy consumption, energy savings, and emission analysis in Malaysian office buildings. Energy Policy, $37(10), 4104-4113$.

United Nations Environment Program. (2015). Why Buildings ? Retrieved April 15, 2015, from http://www.unep.org/sbci/AboutSBCl/Background.asp

Wheeler, A., Boughlagem, D., \& Malekzadeh, M. (2011). Developing a child-friendly post-occupancy assessment methodology for sustainable schools. Third International Conference on Applied Energy, 1-19.

Widman, R. O. N., Kaplan, R., \& Young, R. D. E. (1984). Behavioral Approaches to Energy Conservation in Organizations: A Selected Review of the Literature. East, (November). 